\title{
Combined Method of Nickel Plating of Cotton Fabrics
}

\author{
MALIK SATAEV, SHAYZADA KOSHKARBAEVA, KALAMKAS AMANBAEVA, \\ PERIZAT ABDURAZOVA*, YERKEBULAN RAIYMBEKOV, RAMSHAT ABZHALOV
}

M.Auezov South Kazakhstan State University, High School of Chemical Engineering and Biotechnology, Department of Chemical Technology of Inorganic Substances, Tauke Khan Av., 5, 160000 Shymkent, Kazakhstan

\begin{abstract}
To activate the surface of cotton fabrics before chemical nickel plating, it is proposed to use physical and chemical processes occurring in thin layers of solutions of copper (II) chloride under the influence of electromagnetic solar rays of the visible spectrum. It is shown that cellulose, which is the main component of the fabric, undergoes photo-oxidation in the presence of copper (II) chloride. As a result of this interaction, well-bonded copper monochloride is formed. When further processing of the fabric with phosphine gas, copper monochloride is transformed into copper and copper phosphide. Copper phosphide is a catalyst for the chemical nickel plating process. This makes it possible to obtain an electrically conductive nickel-phosphorus coating on the surface of the fabric in conventional electrolytes of chemical nickel plating. It is also found that when screening individual sections, the processes leading to the formation of copper monochloride do not occur. This allows selective metallization of the fabric.
\end{abstract}

Keywords: cotton fabric, copper (II) chloride, cellulose photo-oxidation, copper monochloride, activation, copper phosphide, chemical nickel plating

\section{Introduction}

The acceleration of technological progress poses new challenges to the industry in the field of fabric production. One of them is the creation of metalized fabrics that perform a certain function. A prominent place among them is occupied by nickel-plated fabrics. Nickel is a relatively inexpensive metal with high chemical resistance and good appearance.

Nickel coating gives fabrics the following functions that allow the use of textiles in the relevant industries:

- decorative appearance, electrical conductivity, which gives fabrics antistatic properties [1];

- creation of an active catalytic layer on the fabric surface of the necessary layer necessary for chemical current sources and devices for producing hydrogen [2, 3];

- giving fabrics a certain electrical resistance allows them to be used as flexible conductive elements, clothing with heating elements [4];

- shielding of electromagnetic radiation and use in various protective devices [5-7];

- radio-absorbing properties that are widely used in modern industry and, especially, in products of the military-industrial complex [8].

Depending on the purpose of fabric materials, the following methods of applying nickel films are used.

To obtain thin surface nickel films on synthetic fabrics, ion-plasma sputtering [1] or vacuum sputtering [9] of the nickel layer is used. Processes are carried out on special installations. Such fabrics have good decorative properties and high electrical conductivity, which allows them to be used as flexible conductive elements and when creating smart textiles [4].

By combining the main threads of the fabric with nickel or nickel-containing polymer threads, a textile material is obtained that can serve as a shield of electromagnetic radiation [5-7]. It is obvious that in this case the difficulties associated with the creation of additional threads.

*email: abdurazova-p@mail.ru 
To obtain special-purpose textile materials, chemical metallization methods are also used. Thus, chemical gas-phase metallization is performed by pumping nickel tetracarbonyl metal vapors through a woven or non-woven material in a shallow vacuum. The source material is heated to the temperature of the beginning of vapor decomposition, and a metal coating is applied over the entire thickness of the bulk material [5]. The disadvantage of the process is the difficulty in obtaining nickel tetracarbonyl and implementing the process.

The most commonly used method of chemical metallization of dielectrics in engineering is that a reaction of formation of catalytic metal ions is carried out on a surface sensitized with divalent tin. Treatment is carried out in solutions of precious metals, mainly palladium. Adsorbed on the surface of the dielectric ions are tin ions restore the palladium. Compounds of germanium (II), iron (II), titanium (III), silicon halides, lead salts, and some dyes are also offered as sensitizers. In addition to palladium, silver, gold, rhodium, ruthenium are also mentioned as catalyst metals [10]. The disadvantage of this method is the use of expensive salts of these metals.

A number of works are devoted to palladium-free activation of the dielectric surface with the production of dispersed copper particles using chemical reducing agents [11-13]. The resulting films do not have sufficient electrical conductivity for the electroplating process, and are not catalysts for chemical nickel plating. This requires the subsequent application of a layer of chemical copper, on which the electroplated nickel is then deposited.

It should be noted that photochemical methods can also be used to activate the dielectric surface. Thus, treatment with solar rays leads to the reduction of silver from its halides [14, 15].

These data show that there are still unsolved problems in existing methods of nickel plating of fabrics, so the creation of new alternative technologies is relevant.

\section{Materials and methods}

Cotton gauze cloth (article No. AA010278), widely used for medical purposes, was used for research. In order to remove industrial contamination, the fabric was pre-prepared by holding it for 30 minutes in hot $\left(70^{\circ} \mathrm{C}\right)$ distilled water. Then, after washing and drying, the samples were cut out. The obtained samples were wetted by dipping for a few minutes in $\mathrm{CuCl}_{2}$ solution. After that, the sample was placed on a glass or polymer surface and smoothed with a glass stick. The amount of $\mathrm{CuCl}_{2}$ solution introduced into the fabric was about $0.5 \mathrm{ml} / \mathrm{dm}^{2}$. After that, the samples were dried under the influence of sunlight. Sunlight is an electromagnetic ray that has a wavelength from 400 to $700 \mathrm{~nm}$. Light waves can also pass through solid bodies, but their intensity decreases. An important characteristic of the rays is the density of the solar radiation flux [16]. To determine this value, the SM206-SOLAR solar radiation meter was used. Studies of the process were carried out in a laboratory room, where the temperature was maintained at $25-30^{\circ} \mathrm{C}$. The permeability during the passage of electromagnetic solar rays of some objects related to this work is shown in Table 1.

Table 1. Permeability of certain materials when passing electromagnetic solar rays of the visible spectrum

\begin{tabular}{|c|c|c|c|c|}
\hline No. & Name of the material & mm Thickness, & $\begin{array}{l}\mathrm{W}, \\
\mathrm{W} / \mathrm{m}^{2}\end{array}$ & $\mathrm{n}, \%$ \\
\hline 1 & In the absence of material & - & 1305 & 100 \\
\hline 2 & Window glass & 4 & 1156 & 88 \\
\hline 3 & White cotton fabric & 0.3 & 351 & 27 \\
\hline 4 & White cotton fabric & 0.1 & 590 & 45 \\
\hline 5 & Black plastic film & 0.05 & 23 & 1.7 \\
\hline 6 & Black plastic film & 2 & 0 & 0 \\
\hline $\begin{array}{l}\text { Desi } \\
\text { W- c } \\
n-d\end{array}$ & $\begin{array}{l}\text { of solar radiation energy } \\
\text { of permeability when the }\end{array}$ & $\begin{array}{l}\text { g through the } \\
\text { es through the }\end{array}$ & . & \\
\hline
\end{tabular}


To conduct experiments, the samples were placed perpendicular to the sun's rays and exposed until completely dry. The color of the sample changed from green (the color of $\mathrm{CuCl}_{2}$ solutions) to black. Black color is typical for fine metal particles formed during chemical reduction.

Moreover, the intensity of the black color of the film depends on the concentration of the original $\mathrm{CaCl}_{2}$ solution in which the fabric was wetted. Therefore, the degree of blackening of the film can be used as an indicator of the content of reduced metal particles in the resulting film. Quantitative characteristics of the intensity of black film samples can be determined using a computer by finding the degree of brightness of the drawing in the work with drawing window. To do this, photos of samples obtained at various stages of the process were placed on white paper and brightness was added for each sample until the image of the drawing disappeared completely. This added brightness was the degree of blackness (as a percentage) of the film on the sample. For example, the degree of blackness in the computer's color palette was $100 \%$.

After photochemical treatment, the samples were washed with distilled water to remove the reaction byproduct $(\mathrm{HCl})$ and excess $\mathrm{CuCl}_{2}$, and dried at room temperature for $30 \mathrm{~min}$. The slightly moistened fabric contained only copper chloride (1). In some experiments, part of the fabric surface was shielded with a black polymer washer with a thickness of $2 \mathrm{~mm}$, which prevents the sun's rays from penetrating the fabric (Table 1).

This sample was then placed in a sealed chamber for treatment with phosphine gas $\left(\mathrm{PH}_{3}\right)$. Phosphine is a strong reducing agent and, when interacting with the surface film, reduces copper (I) chloride to elemental copper and copper phosphide [17]. In addition, phosphine contributes to the formation of copper phosphide in the surface film, which gives it catalytic properties that allow it to obtain a chemical nickel coating of the required thickness that is resistant to atmospheric conditions [18].

Therefore, after washing the samples from the reaction byproducts, they were immersed in a chemical nickel-plating electrolyte. An electrolyte of the following composition was used in the research, g/l:

Nickel sulfate heptahydrate $\mathrm{NiSO}_{4} \cdot 7 \mathrm{H}_{2} \mathrm{O}-22-26$;

Sodium hypophosphite hydrate $\mathrm{NaH}_{2} \mathrm{PO}_{2} \cdot \mathrm{H}_{2} \mathrm{O}-30-34$;

Ammonium chloride $\mathrm{NH}_{4} \mathrm{Cl}-25-30$;

Acetic acid $\mathrm{CH}_{3} \mathrm{COOH}-18-22$;

Ammonia (25\%) $\mathrm{NH}_{3}$ before $p \mathrm{H} \mathrm{8,6-8,9.}$

The process was performed at room temperature for $1 \mathrm{~h}$. The specific load was $2 \mathrm{dm}^{2} / \mathrm{L}$. To determine the electrical conductivity of the resulting films, a DT-830B resistance tester was used.

The structure and composition of films at separate stages of the process were studied using a raster electron microscope ISM-6490-LV (JEOL, Japan). The device allows you to get an electronic image of particles with a size of tens of nanometers, the element composition and the percentage of elements in the surface layers of the film.

\section{Results and discussions}

To apply nickel coatings to fabrics, the following basic operations are required:

- creating an indelible layer of copper chloride (I) on the surface of the fabric);

- transformation of chloride (I) to copper phosphide;

- obtaining a metal coating by chemical nickel plating.

The creation of an indelible layer of copper monochloride on the surface of the fabric was carried out by exposure to solar radiation on the surface of the fabric, previously moistened with a solution of $\mathrm{CuCl}_{2}$. The cellulose that makes up the fabric contains three alcohol hydroxyl, which in certain cases can be subjected to oxidation. When drying such a fabric under the influence of sunlight, cellulose is photo-oxidized by reaction 1 . In this case, the role of the oxidizer is performed by $\mathrm{CuCl}_{2}$.

$$
2 \mathrm{CuCl}_{2}+\mathrm{H}_{2} \mathrm{O}+\mathrm{R}-\mathrm{OH} \rightarrow 2 \mathrm{CuCl}+2 \mathrm{HCl}+\mathrm{R}-\mathrm{OOH}
$$


where R - the elementary unit of cellulose.

Monovalent copper chloride is a binary semiconductor, so when photons are exposed to electromagnetic rays of sunlight, some of the electrons passes into the conduction band and acquire the ability to restore monovalent copper

$$
\mathrm{CuCl}+\mathrm{e} \rightarrow \mathrm{Cu}+\mathrm{Cl}^{-}
$$

where $\mathrm{E}^{\mathrm{o}}$ - the standard potential of the electrochemical reaction

After that, vacancies remain in the semiconductor, for which only $\mathrm{CuCl}$ and a water molecule can be used as electron donors. If we consider that the oxidation of water molecules at a $\mathrm{pH}$ of less than 7 requires a potential of more than $0.8 \mathrm{~V}$, then the preferred electron donors will be $\mathrm{CuCl}$ molecules.

$$
\mathrm{CuCl}+\mathrm{Cl}^{-}-\mathrm{e} \rightarrow \mathrm{CuCl}_{2}
$$

The electromotive force of the reaction 2 and 3 is $-0.401 \mathrm{~V}$. Therefore, the additional energy received from the sun's rays must provide a real voltage in the system exceeding this value. In this case, a photochemical reaction will occur.

$$
2 \mathrm{CuCl} \stackrel{\mathrm{h} v}{\longrightarrow} \mathrm{Cu}+\mathrm{CuCl}_{2}
$$

Moreover, $\mathrm{CuCl}_{2}$, when the surface film dries, crystallizes and loses its activity, which is an additional factor contributing to the reaction 4.

The resulting particles of elemental copper give the film a black color characteristic of metals obtained from salt solutions using various reducing agents.

Figure 1 shows images of a fabric sample before (a) and after (b) applying a photochemical copper film. Measurements of the degree of blackness according to the above method showed that for the original fabric, this value is $22 \%$, and after applying the film, $65 \%$. The formation of a black film on the surface of the tissue shows the possibility of reaction 4 .

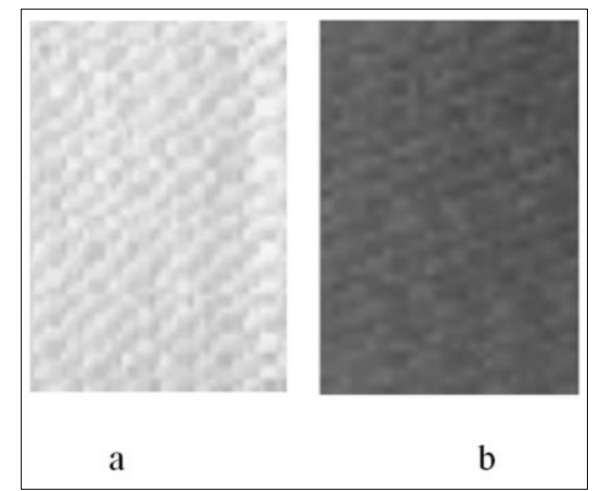

Figure 1. Images of the fabric (a) before and (b)

after application of a photochemical film of copper (112 DPI resolution)

During subsequent washing with water, the non-reacting 1 part of the original $\mathrm{CuCl}_{2}$ is removed. In addition, this leads to the disappearance of the black color of the fabric. Therefore, the secondary $\mathrm{CuCl}_{2}$ formed by reaction 4 is not removed during washing, but remains in the structure of the binary semiconductor. Under the influence of water, it is activated again and contributes to the flow of reaction 4 from right to left. This is confirmed by the fact that if the washed fabric is dried again under the sun, the black film appears again. Moreover, the degree of blackness is practically unchanged. Thus, as a 
result of photochemical processes, a layer of elemental copper (if the fabric is dry) or a layer of monochlorous copper (if the fabric is moistened) is formed on the surface of the fabric.

Electromagnetic rays of the sun can partially penetrate the fabric material, and the oxidation process begins at the surface of the fiber, and then gradually moves to deeper layers, while first the amorphous part is oxidized, and then the crystalline sections. This leads to the fact that the formation of $\mathrm{CuCl}$ occurs both in the surface and deep layers of the fabric. As a result, there is a good connection between the copper, it and the fabric. Perhaps chemosorption is taking place here.

The photochemical character of the processes is confirmed by experiments with shielding a part of the surface with black polymer washers ( $2 \mathrm{~mm}$ thick) that are impermeable to the sun's rays (Table 1). The shielded areas do not produce copper monochloride by reaction 1 , and $\mathrm{CuCl}_{2}$ can be washed with water (Figure 2). This allows selective metallization of fabric materials.

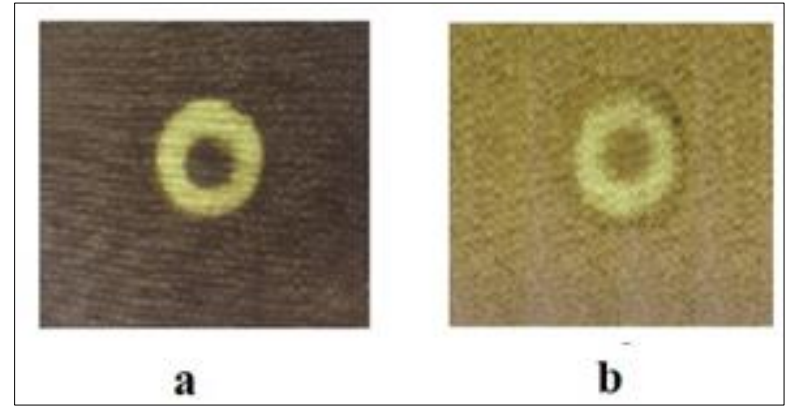

Figure 2. Photochemical films on fabric samples

from the side facing the solar radiation (a) and from the opposite side (b)

The presence of permeability of electromagnetic rays through the fabric (Table 1) ensures the flow of photochemical reactions on the reverse side of the fabric. In this case, the degree of blackening of the back side is always lower than the front side (Figure 2, b). This is due to the weakening of electromagnetic solar rays when passing through these materials. At the same time, measurements showed that the degree of blackness of the front side is $73 \%$, and the reverse is $61 \%$. This makes it possible to obtain a metal coating simultaneously on both sides of the fabric.

An important factor affecting the process of obtaining surface films of copper or its monovalent chloride is the concentration of $\mathrm{CuCl}_{2}$ in the solution for wetting the fabric. The effect of $\mathrm{CuCl}_{2}$ concentration on the photochemical reduction of copper was studied by determining the degree of blackness in the process of drying samples under the influence of sunlight (Figure 3). The initial sections of the curves are associated with the evaporation of water from solution in the surface layer of fabric, leading to increased concentrations of copper chloride and also by the speed of photochemical reactions.

The appearance of horizontal sections on curves 3 and 4 is associated with saturation of active cellulose sections and further increase in the concentration of $\mathrm{CuCl}_{2}$ does not affect the copper content. The value of this limit concentration depends on the physical and chemical properties (grade) of a particular fabric. For the studied fabric, this limit concentration was $50 \mathrm{~g} / \mathrm{L}$ (Figure 3).

Thus, when exposed to electromagnetic rays, a well-bonded film consisting of copper monochloride is formed. To impart catalytic properties, it is proposed to transform it into copper phosphide. This transformation was carried out by treatment with phosphine gas.

$$
12 \mathrm{CuCl}+3 \mathrm{PH}_{3}+3 \mathrm{H}_{2} \mathrm{O} \rightarrow 2 \mathrm{Cu}_{3} \mathrm{P}+6 \mathrm{Cu}+\mathrm{H}_{3} \mathrm{PO}_{3}+12 \mathrm{HCl}
$$




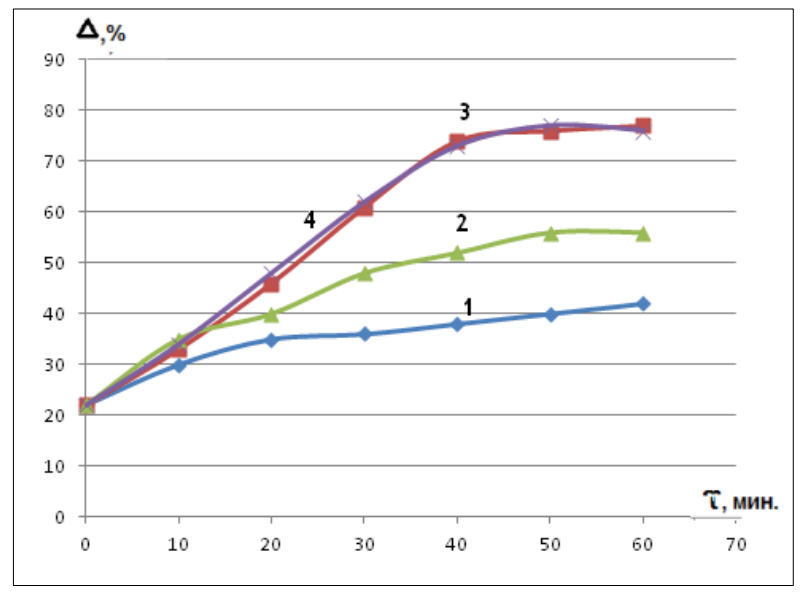

Figure 3. Change in the degree of blackness of fabric samples moistened with solutions of copper bichloride under the influence of sunlight.

Concentration of copper dichloride, g / 1: 1-10; 2-20; 3-50; 4-60

After treatment with phosphine (Figure 4, Table 2), the fabric acquired a stable dark color, which did not change when washed with water. The dark color is characteristic of copper phosphide $\mathrm{Cu}_{3} \mathrm{P}$. Elemental analysis also showed the appearance of phosphorus in the surface film. The analysis also showed the presence of chlorine in the surface film. This may be due to the partial oxidation of copper, which leads to the formation of insoluble basic copper chloride. Moreover, this compound does not affect the process of chemical nickel plating.

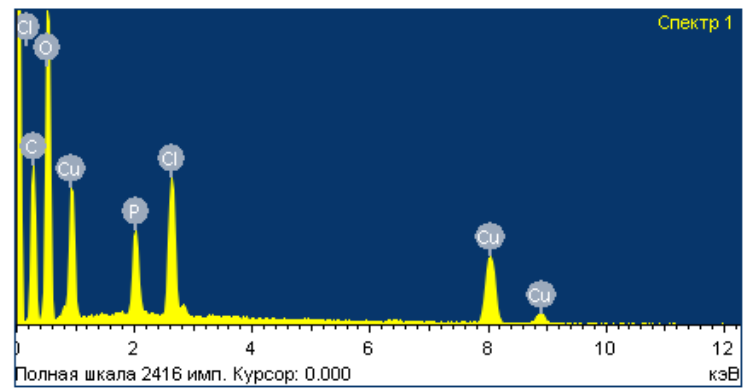

Figure 4. Spectra of surface films after phosphine treatment

Table 2. Elemental composition of surface films after phosphine treatment

\begin{tabular}{|c|c|c|}
\hline Element & Weight, $\%$ & Atomic, $\%$ \\
\hline $\mathrm{C}$ & 38.88 & 53.79 \\
\hline $\mathrm{O}$ & 36.61 & 38.03 \\
\hline $\mathrm{P}$ & 2.82 & 1.51 \\
\hline $\mathrm{Cl}$ & 4.81 & 2.25 \\
\hline $\mathrm{Cu}$ & 16.88 & 4.41 \\
\hline Total & \multicolumn{2}{|c|}{100.00} \\
\hline
\end{tabular}

Chemical nickel plating in the electrolyte usually used in practice made it possible to obtain an electrically conductive film on the fabric without much difficulty. The process was performed at room temperature for 1 hour. At a loading density of $2 \mathrm{dm}^{2} / \mathrm{L}$, an electrically conductive coating $\left(\mathrm{p}=7 \times 10^{-7}\right.$ Om $\times m$ ) was obtained (Figure 5). Visual comparison of the diameters of the outer threads of the fabric 
in Figure 5 showed an increase of 1.3-1.6 microns. At the same time, high electrical conductivity was both illuminated by the sun's rays, and the reverse side of the fabric.
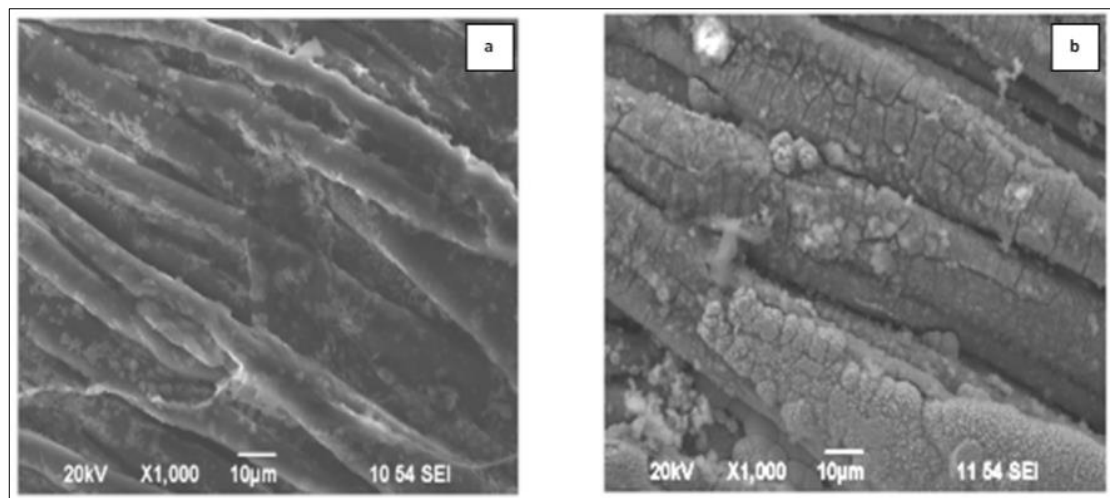

Figure 5. SEM images of fabric samples after treatment with phosphine (a) and after chemical nickel plating (b)

Spectral analysis of the surface layer showed that the film has a composition characteristic of coatings obtained by chemical nickel plating. At the same time, the fabric has a soft neck, air and moisture permeability, and retains its strength characteristics (Figure 6, Table 3).

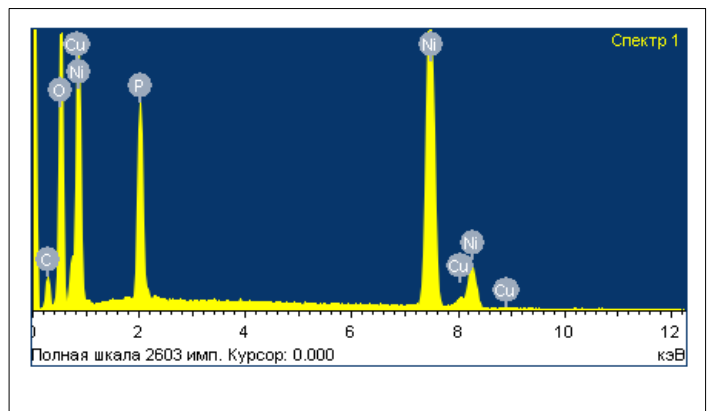

Figure 6. Spectra of surface films after chemical nickel plating

Table 3. Elemental composition of surface films after chemical nickel plating

\begin{tabular}{|c|c|c|}
\hline Element & Weight, $\%$ & Atomic, $\%$ \\
\hline $\mathrm{C}$ & 10.35 & 24.58 \\
\hline $\mathrm{O}$ & 21.71 & 38.70 \\
\hline $\mathrm{P}$ & 8.66 & 7.98 \\
\hline $\mathrm{Ni}$ & 57.96 & 28.15 \\
\hline $\mathrm{Cu}$ & 1.32 & 0.59 \\
\hline Total & \multicolumn{2}{|c|}{100.00} \\
\hline
\end{tabular}

\section{Conclusions}

The following basic processes were used for nickel plating of cotton fabrics. Pre-soaked in a solution of dichloride of copper were dried by exposure to sunlight. At the same time, due to the influence of electromagnetic waves of solar radiation, cellulose (the main component of the fabric) was oxidized and copper monochloride was formed. The permeability of electromagnetic waves leads to the formation of copper monohydrate on both sides of the fabric. Moreover, copper monochloride is strongly bound to the fabric and can withstand numerous washings.

This fabric was then exposed to phosphine gas. In this case, copper and copper phosphide are formed as a result of reducing processes. Copper phosphide is a catalyst for the chemical nickel plating process. 
This made it possible to apply an electrically conductive nickel-phosphorous coating to the fabric using a chemical method. Moreover, when screening individual areas at the stage of processing by solar rays, the metal coating can be selective. This allows you to use this technology to get smart fabric.

Acknowledgments: This research is funded by the Science Committee of the Ministry of Education and Science of the Republic of Kazakhstan (Grant No. AP08956891).

\section{References}

1.*** Official web-site of BStudy Education portal. Available online:

https://bstudy.net/675952/meditsina/ekraniruyuschie_tkani_zaschity_elektromagnitnyh_izlucheniy: URL (accessed on 10 June 2020).

2. Official web-site of Chemical Components Factory "Ekotec". Available online: https://www.ekotec.ru/product/5158819/ : URL (accessed on 10 June 2020).

3. MOROZOVA, A., SELIVANOV, P., Ispol'zovanie nikelirovannogo uglerodnogo volokna v kachestve osnovy oksidno-nikelevogo jelektroda [in Russian: Using nickel-plated carbon fiber as the base of a nickel oxide electrode]. Jelektrohimicheskaja jenergetika, 3(10), 2010, 133-136.

4. WILliAM, S., Smart Textile Coatings and Laminates: 2nd Edition, Cambridge, Woodhead Publishing, 2018, 290.

5. UEHL'SKIJ A., SYRKIN, V., GREBENNIKOV, A., CHERNYSHEV, E. 2001, Russian Federation Patent No. 2171858.

6. MAREICHEV, A., KAPITONOV, V., POPOV, G. 1993, Russian Federation Patent No. 2000680.

7. Official web-site of Ebay. CYBER Faraday Fabric EMF RF RFID Shielding Nickel Copper - 50" x 1' Roll. Available online:

https://www.ebay.com/itm/CYBER-Faraday-Fabric-EMF-RF-RFID-Shielding-Nickel-Copper-50-x-1Roll-/131893315404: URL (accessed on 10 June 2020).

8. Official web-site of "RT-Tehnologii". Radar absorbing materials, absorbers of microwave energy for the series ZIPSIL RPM made in Russia. Available online: https://www.rttex.ru/microwave-absorbersseries/ : URL (accessed on 10 June 2020).

9. GAPPAROV, Kh., KHOMIDOV, I., FAYZIEVA, G., Vidy i sposoby metallizirovanija tekstil'nyh materialov dlja poshiva special'noj odezhdy [in Russian: Types and methods of metallized textile materials for sewing special clothing]. Molodoj uchenyj, 11, 2016, 310-313.

10. KAPITSA, M., Aktivacija poverhnosti dijelektrika [in Russian: Activation of the dielectric surface]. Tehnologii v jelektronnoj promyshlennosti, 5, 2005, 22-25.

11. PAVLJUKHINA, L., ZAJKOVA, T., ODEGOVA G. 1997, Russian Federation Patent No. 2074536. 12. RYASHENTSEVA, G., LOMOVSKIY, O., Kataliticheskaja aktivnost' mednyh chastic v reakcii himicheskogo mednenija [in Russian: Catalytic activity of copper particles in the chemical copper plating reaction], Zhurnal prikladnoj himii, 71(2), 1998, 264-267.

13. FINAENOV, A., ZAKIROVA, S., RAKHMETULINA, L., KRASNOV, V., NEVERNAYA, O. 2016, Russian Federation Patent No. 2588918.

14. ABDURAZOVA, P.A., NAZARBEK, U.B., BOLYSBEK, A.A., SARYPBEKOVA, N.K., KENZHIBAYEVA, G.S., KAMBAROVA, G.A., SATAEV, M.S., KOSHKARBAEVA, Sh.T., TLEUOVA, A.B., PERNI, S., PROKOPOVICH, P., Preparation of photochemical coatings of metal films (copper, silver and gold) on dielectric surfaces and studying their antimicrobial properties, Colloids and Surfaces A: Physicochem. Eng. Aspects, 532, 2017, 63-65.

15. SATAEV, M.S., KOSHKARBAYEVA, S.T., ABDURAZOVA, P.A., ABZHALOV, R.S., NAZARBEK, U.B., ISSAEVA, R.A., Photochemical Method of Depositing Silver Films on the Surface Cotton Fabrics, Orient J Chem, 34(6), 2018, 2755-2761. 
16. MELNIKOV, V., Vozobnovljaemye istochniki jenergii. Uchebnye materialy dlja lic, prinimajushhih reshenija $v$ stranah Central'no-Aziatskogo regiona [in Russian: Renewable energy source. Training materials for decision makers in the Central Asian region], Almaty, UNESCO Central Asian office, 2011, 225.

17. SATAEV, M.S., SYRMANOVA, K.K., SALYBAEV, A.S. Mehanizm himicheskogo nikelirovanija osnov, pokrytyh med'-fosfornymi plenkami [in Russian: Mechanism of chemical nickel plating of bases covered with copper-phosphorous films], "Khimiya i khimicheskaya tekhnologiya" Russian Journal of Chemistry and Chemical Technology, 47(4), 2004, 70-71.

18. SATAEV, M.S., KOSHKARBAEVA, S.T., TLEUOVA A.V., PERNY, S. AIDAROVA, S.V., PROKOPOVICH, P. Novel process for coating textile materials with silver to prepare antimicrobial fabrics, Colloids and Surfaces A: Physicochem. Eng. Aspects, 412, 2014, 146-151

$\overline{\text { Manuscript received: } 13.06 .2020}$ 